\title{
Alternative education and social justice: Considering issues of affective and contributive justice
}

\author{
Martin Mills ${ }^{\mathrm{a}}$, Glenda McGregor ${ }^{\mathrm{b}}$, Aspa Baroutsis ${ }^{\mathrm{a}}$, Kitty te Riele ${ }^{\mathrm{c}}$ and Debra Hayes ${ }^{\mathrm{d}}$ \\ ${ }^{a}$ School of Education, The University of Queensland, Brisbane, Australia; ${ }^{b}$ School of Education \\ and Professional Studies, Griffith University, Brisbane, Australia; ${ }^{c}$ The Victoria Institute of \\ Education, Victoria University, Melbourne, Australia; ${ }^{d}$ Faculty of Education and Social Work, \\ Sydney University, Sydney, Australia.
}

Corresponding author: m.mills@uq.edu.au

This paper considers the ways in which three alternative education sites in Australia support socially just education for their students and how injustice is addressed within these schools. The paper begins with recognition of the importance of Nancy Fraser's work to understandings of social justice. It then goes on to argue that her framework is insufficient for understanding the particularly complex set of injustices that are faced by many highly marginalised young people who have rejected or been rejected by mainstream education systems. We argue here for the need to consider the importance of 'affective' and 'contributive' aspects of justice in schools. Using interview data from the alternative schools we highlight issues of affective justice raised by students in relation to their educational journeys, as well as foregrounding teachers' affective work in schools. We also consider curricular choices and pedagogical practices in respect of matters of contributive justice. Our contention is that the affective and contributive fields are central to the achievement of social justice for the young people attending these sites. Whilst mainstream schools are not the focus of this paper, we suggest that the lessons here have salience for all forms of schooling.

Keywords: social justice, affective justice, contributive justice, alternative education, youth studies

Acknowledgements: This work was supported by the Australian Research Council under Grant DP120100620. 


\section{Introduction}

This paper has evolved from a project exploring the types of learning occurring in flexible learning sites/alternative ${ }^{1}$ education in Australia during the period 2012-14. The project was concerned with the ways in which such sites supported a socially just education for their students. Our concerns were framed around Nancy Fraser's (1997; 2009) conceptions of social justice in that we were interested in the ways in which such schools took account of: issues of distribution, or the economic injustices faced by the young people attending the schools; issues of recognition, that is, the cultural injustices faced by these young people; and issues of representation, with regards to the political injustices experienced by young people.

In the main we have been impressed by what these schools do in relation to addressing all of these forms of injustice (see for example, McGregor et al. 2015; Mills et al., 2015). However, to us there was something missing in the analysis when it came to describing the types of relationships that support young people's engagement in schooling, as well as those that disrupt this engagement. We have come to the conclusion that social justice is a complex and multifaceted concept that is inadequately explained by Nancy Fraser's framework and we suggest here that there are other elements that need to be considered when addressing issues to do with socially just education. In so doing we are drawn to both the work of Kathleen Lynch (2012) and Andrew Sayer (2009, 2011). Lynch (2012) in her critique of Fraser's theory suggests that 'it does not recognize the affective domain of life as a discrete site of social practice' (p. 49). In terms of schooling, the affective sphere is concerned with the quality of relationships, care and support available to students. Interrelated with this is Sayer's qualitative understanding of 'contributive

\footnotetext{
${ }^{1}$ In this paper, we have used the terms flexible learning centre and alternative school somewhat interchangeably. We note, as do Mills \& McGregor (2014) that there is no agreed-upon definition and much contestation regarding what constitutes 'alternative education'. The schools involved here are those that cater to marginalised young people and are also often referred to as 'second chance' schools.
} 
justice' and its relationship to meaningful work. Based on our own observations of multiple alternative schooling sites in Australia and England (see for example, Baroutsis et al. (in press); Hayes, 2013; McGregor et al., 2015; Mills \& McGregor, 2010, 2014; Mills et al., 2013; Mills et al., 2014; te Riele, 2012, 2014; te Riele, Davies \& Baker, 2015), and drawing on notions of contributive justice we suggest, that 'care' needs to be taken in the provision of flexible education to ensure students do not receive a watered down curriculum that fails to engage them intellectually and that damages their sense of self-respect.

The paper begins with an outline of the research project and its relationship to the work of Nancy Fraser; we then move on to discuss concepts of affective justice and contributive justice and their relevance to schooling, contextualising our theories with interview data collected from teachers and students in flexible learning sites situated in three different Australian jurisdictions. We highlight those issues of affective justice raised by students both in relation to their former and current schools, and we foreground teachers' affective work in schools. A consideration of the types of curricula and pedagogical practices present in these schools and their relationship to contributive justice support our contention that such approaches are central to the achievement of social justice for the young people attending these sites. Whilst our focus is on young people in alternative forms of education, we suggest that the lessons here have salience for all forms of schooling.

\section{Flexible learning and social justice}

We, like others (see for example, Cribb \& Gewirtz, 2003; Lipman, 2008; Power \& Frandji, 2010; Keddie 2012a, 2012b), have found the work of Nancy Fraser useful in considering what a socially just school might look like. Her work has focussed on considering how the sometimes competing demands of economic justice and cultural justice can be worked together to provide a 
comprehensive theory of justice. In more recent times she has embedded a concern with political justice into her theoretical framework.

Within Fraser's framework economic injustice refers to an inequitable distribution of resources and the damaging effects of this 'maldistribution'. Cultural injustice refers to the ways in which various groups are have become 'despised', for example, on the grounds of sexuality, gender, or race/ethnicity. This ‘misrecognition' occurs when people are forced to suppress their own cultural ways of being and communicating to the (often hostile) norms of the dominant culture, are rendered invisible or are disrespected as a result of belonging to a particular cultural group. Political injustice, which Fraser refers to as 'misrepresentation', occurs in those instances when people are denied an opportunity to make justice claims when they are experiencing economic or cultural injustice or when they are unable to contribute to the decisions that impact upon their lives. She contends that misrepresentation can occur (although unlikely) in the absence of economic and cultural injustices. Fraser argues that all such aspects of injustice have to be attended to in order to achieve a socially just society where there is 'parity of participation'. Her work has not been without its critics (see for example, Olsen, 2008). However, we have found this framework a useful device for considering how economic, cultural and political injustices, and their respective solutions of distribution, recognition and representation, relate to contemporary schooling, both in the mainstream and alternative sectors (see for example, McGregor et al. 2015; Mills et al., 2015).

Mainstream schools have a long history of not serving particular groups of young people well. Students who come from low socioeconomic backgrounds are disproportionately represented in the lower bands of achievement and attendance data and in the upper bands of data on exclusion, suspension and 'special needs'(see for example, Abrams, 2010; Evans et al., 
2009; Gale \& Densmore, 2000; Kane 2011; Mills \& Gale, 2010; Mosen-Lowe, Vidovich \& Chapman, 2009). Multiple reasons for this have been suggested to us by participants in our study. These include, students' access to particular forms of cultural capital, lack of fit between the middle class expectations of schooling and (non)working class culture, teacher prejudices, lack of resources, and even diet. Whilst we have very definite understandings of our own as to why this is the case, we would also suggest that whatever the reason, there is no doubt that an injustice is being perpetrated against the children of the poor. This economic injustice works to ensure that the benefits of schooling are unfairly distributed amongst young people according to their family’s economic circumstances, and given the strong relationship between educational success and social mobility (OECD, 2012) reproduces existing patterns of wealth and poverty. In many of the schools we have visited, this injustice has been addressed through, for example, the provision of food, accommodation support for homeless young people, transportation, basic services (for example, showers) and free excursions (see for example, Mills \& McGregor, 2014).

Defining 'culture' in its broadest sense to include gender, sexuality, race/ethnicity, religion, language background and so on, it is clear that young people who belong to marginalized 'cultures' often encounter schooling as a less than positive experience. This 'cultural injustice’ can be shaped by a lack of academic reward, but also by harassment and violence, by being ignored, silenced or having one’s existence denied, by active and hidden discrimination at multiple levels, and it can be perpetrated by teachers and students alike (Smyth, 2006). In many of the flexible schools we have visited, this injustice has been addressed by a strong commitment to recognising and valuing difference. This has been demonstrated through, for example, seeking input from local Indigenous Elders into organisational and curriculum 
content, the provision of crèches for those students who have children, ensuring that homophobia or racism are never ignored and providing support around domestic violence issues.

It is also apparent that many young people experience schooling as oppressive because they have no forum in which to express their opinions or challenge the injustices they have experienced (Black, 2011). The importance of student voice in schools has been well documented (see Dewey 1916; Beane \& Apple 1999; Fielding \& Moss 2011), however its presence is often lacking. An absence of voice, or political injustice, may be apparent in the ways in which students, especially those from marginalized backgrounds, can be summarily suspended from school, given detentions and other forms of punishment without options to challenge those decisions. It is apparent in dress codes, in timetabling restrictions, in the appointment of teachers and in curriculum decisions. It is perhaps not surprising, as Teese and Polesel (2003) indicate, that for many young people who are not achieving well at school, their most common descriptor of school is as a prison. In the schools that we have visited as part of this project we have seen attempts to give students a voice through regular community meetings (Baroutsis, McGregor \& Mills, in press), through consultations on renovations, even in one case working closely with architects to design new premises, and by including them on teacher interview panels.

Whilst in the main we have been highly supportive of these alternative schools and the various ways in which they have worked to challenge injustice (see for example, Hayes, 2012; Mills \& McGregor, 2014; te Riele, 2006; 2007; 2011), we are of the view that as a matter of social justice these schools also have to consider the types of learning that students do in the classroom. It has been noted in many studies, and compounded by an era of high stakes testing (Darling-Hammond, 2010; Lingard, Martino \& Rezai-Rashti, 2013; Hardy, 2013; Lingard \& Sellar, 2013), that many classrooms in mainstream schools are devoid of curriculum, pedagogy 
and assessment that inspire, challenge and provoke all students (Hayes et al., 2006; Smyth, McInerney \& Fish, 2013). However, whilst concerned about this current state of affairs, we are of the view that such an absence in flexible learning centres is particularly damaging to those students who have already been disenfranchised from learning. We are not alone here.

There have been some concerns raised about the alternative education sector being constructed as a dumping ground for students 'unwanted' by the education system where there is then little academic challenge (Mills, Renshaw, \& Zipin, 2013; Kim \& Taylor, 2008; Kim, 2011; Smyth, McInerney and Fish, 2013). de Jong and Griffiths (2006), for instance, have expressed concerns that the increased use of alternative education programs for younger and younger students can lead to them being separated from the mainstream and its benefits, and that 'poorly constructed and resourced' programs will reinforce students' poor outcomes from schooling (p. 37). Thus, in highlighting the necessity for elements of affective justice and contributive justice to be significant considerations when working with disenfranchised young people, we are not suggesting that 'care' by itself is sufficient to address all their needs. Our intention is to tease out the complexity inherent in notions of a 'socially just' education as explained in the following sections.

\section{Multi-sited ethnography}

This study represents a ‘multi-sited ethnography’ of alternative schools (Falzon, 2009; Marcus, 1995; Pierides, 2010; Kraftl, 2013). Marcus (1995) explains that this mode of ethnographic research 'moves out from the single sites and local situations of conventional ethnographic research designs to examine the circulation of cultural meanings, objects, and identities in diffuse time-space' (p. 96). The strength of multi-sited ethnography is that it enables the researchers to 'make connections between sites' (Pierides, 2010, p. 186) in a 'spatially dispersed field through 
which the ethnographer moves' (Falzon, 2009, p. 2). In this research project, we used ethnographic observations and semi-structured interviews with students, teachers and other workers in three flexible learning schools across three Australian states and one territory during multiple visits over a period of 18 months in 2013 and 2014. We sought to explore a range of themes that included the following broad areas, as relevant to teachers, workers and students: previous experiences; pathway into the alternative site; reasons for staying; what works (relational, material, pedagogical and curricular elements) and why; and, resourcing and sustainability issues. In this paper we draw upon data from three of these sites, identified using the pseudonyms: Elkhorn Community College in Queensland; Banksia College in the Australian Capital Territory; and Boronia Flexi School in Victoria, in order to explore concepts of affective and contributive justice that emerged as significant concerns within these schools.

Elkhorn Community College is a non-government and non-fee paying school providing educational programs for young people in Years 10, 11 and 12, the final three years of secondary education in Australia. At the time the researchers were at the College, there was an enrolment of approximately 60 young people and five staff, comprising a principal, two teachers, and two youth and community development workers (one of whom was completing teaching qualifications). Banksia College is a mainstream government senior high school in a major Australian city that runs two alternative programs (now both operating out of the main campus) for students who have difficulties fitting into the mainstream and usually come from very difficult personal circumstances: one is a flexible learning centre for approximately 100 pregnant girls and young parents (mostly mothers) who attended both part and full-time; the other is a 
'Big Picture'2 inspired offering with a focus on flexibility of delivery and project-work for approximately 35 students. Staffed by small teams of dedicated teachers, both programs provide significant levels of material and personal support to the young people in their care. Boronia Flexi School is a metropolitan Year 7-12 alternative school and is part of the Edmund Rice Education Australia (EREA) Youth+ network, which 'seeks to respond to the needs of young people disenfranchised and disengaged from education. This non-fee paying school caters to approximately 130 students, and as with Elkhorn and Banksia, their life experiences have been challenging - including poverty, mental illness, out-of-home care, drug dependency, juvenile justice and settlement as recent migrants. Boronia Flexi School offers Year 7-12 formal junior and senior secondary credentials.

In the following sections of the paper, we consider affective and contributive injustice. Affective justice relates very much to the relationship and supportive structures that are in place within a school that indicate to young people that they are cared about. We would suggest that learning approaches which appear to have no purpose to the student and provide little by way of satisfaction and serve to demoralise them, not only represent an affective injustice, a lack of care, but also constitute a contributive injustice. Such learning would include, for example, routinized test skilling, worksheets, and form filling with an emphasis on basic skills. This does not mean that some rote learning or the developing of skills have no place in the delivery of meaningful learning, but that they need to be part of a broader approach to learning not an end in themselves. We then provide examples of affective and contributive justice, where all students are engaged in

\footnotetext{
2 The Big Picture model of schooling has its origins in the USA. Its basic principles articulated on its Australian website state: 'highly personalised approach to education combines academic work with real world learning. It places the student, their passions and their interests, at the centre of the learning process'. (Big Picture Education Australia 2014)
} 
meaningful work in a caring and supportive environment. This has particular salience given the context of where these justice acts are taking place. The schools that form the basis of our case study sites are those whose students, in the most part, have not been previously engaged in learning, have been labelled as academically and socially deficit and yet are now willing to come to school. We would suggest that this emphasises the importance of all schools demonstrating a commitment to affective and contributive justice.

\section{Affective justice and learning environments}

The relational and caring dimensions of schooling have been widely recognised (Bingham \& Sidorkin, 2004; Noddings, 1988) and these are arguably particularly important when working with students who have experienced marginalisation in school and society (Beck \& Cassidy, 2009; Smyth et al., 2008; te Riele, 2006). Additionally, many feminist writers have stressed the political importance of emotions and understandings of 'affective justice’ (Blackmore, 1999, 2006; Boler, 1999; Hochschild, 1983). As Lynch (2012), has indicated it is often feminist scholars who 'have drawn attention to the salience of care and love as goods of public significance' (p. 47). Her work informs our concern with social justice and alternative education. Those schools deemed alternative, as all schools, are communities where their success in terms of being a place where both workers and students want to attend, is dependent upon the quality of relationships for all. As with Lynch, we recognise that the care provided by members of that community to each other is a matter of social justice both in relation to who gives it and who receives it (Lynch, 2012, p. 49). She argues that what she refers to as 'affective equality' is focussed on two issues: 'securing equality in the distribution of the nurturing through love, care and solidarity relationships and securing equality in the doing of emotional and other work involved in creating love, care and solidarity relations' (p. 50). 
Whilst we are concerned with the issue of who is responsible for 'caring', and recognise the mutuality of such caring, our focus here is on who gets the 'caring'. Many of the young people in our study, when asked to outline the strengths of their current schools suggested that it was the relationships that mattered, that they felt that the teachers and other workers cared for them. This was often contrasted with previous experiences of schooling, for example Audrey, a Boronia Flexi School student said the following of her current school:

They care, they care a lot about the students. No matter who you are they care ... Because they're so sweet, they do so much for the students here and more than what other schools would do because the way I've seen in other mainstream schools is you're a teacher, you teach, that's it. They're more caring. Like I say, it’s like a community, it’s like a family. So the teachers really care about the students and they're also youth workers as well so they deal with the children. If you have something on your mind you talk to a teacher and they're full open with you and they're so nice, they're just the most nicest people here.

Lynch outlines three sets of relations that constitute affective justice: love, care and solidarity. In the first instance, love is said to be related to relationships of high interdependency and intense engagement; she suggests that even when such relationships are absent they often have great significance (for example the parent-child relationship even in abusive situations). Care relations are viewed as having a lower order of dependency and obligations, but are significant nonetheless; she suggest that friends, work colleagues and some distant relations fall into this category. Solidarity relations do not involve intimacy, but are, Lynch (2012) suggests, ‘the more political or public face of affective relations' (p. 52). Here we can think of advocate groups (for example, refugee support groups), unions and government departments. Lynch suggests that these three categories are not mutually exclusive and that they are interdependent. She also argues that these systems of ‘affective equality’ are all interrelated with Fraser’s 
framework. She argues that 'it is not possible to address problems of inequality or social justice in one social system therefore without addressing those in related social systems' (p. 53). We contend that it is the relational sets of 'care' and 'solidarity' that construct the affective domain within schools and that these elements are especially important for achieving socially just outcomes for marginalised young people.

Applying Lynch’s (2012) conceptualisation of ‘relational care work’ (p. 56) in alternative settings suggests that teachers play an important mediating role at the nexus of these relationships: supporting and working with students and their families or caregivers; developing flexible structures and processes that provide a caring schooling environment; and working in solidarity with students to resist their continued marginalisation in schooling and beyond. For example Faye, who attended Banksia College commented:

I got kicked out of home and I came in and saw the counsellor and straight away she got me straight onto housing. They do that little bit extra all the teachers here. It's more than just what a normal teacher does at a school. They look out for you in your entire life, not for just the six hours that I'm here for.

Additionally, many of the students we interviewed talked about how their prior schooling experiences contributed to the complexity of their lives, rather than providing a place of care and support. Drew, a student from Elkhorn Community College provided us with an example:

I was always 'your bad student'. I wasn't bad. Like, I was respectful in some ways but I couldn't concentrate on work and it was, like, hard, just coming from my old life ... drugs, drinking and wrong people and violence and - yeah.

Leanne, a student at Banksia College, contrasted her experiences with her former and current school. She said of the program at Banksia: 
We get to come into school and you are not stressed. Like, when you have got family issues and that, you can sit down and, like, talk to Leigh and Stuart (teacher and deputy principal) and they will, like, help you through the day and that. And then you can go and make yourself a cup of tea. It's more relaxed and chilled. Like, you are not stressed about going into class and that. You are running a bit late on an assignments - they do help you out.

Irrespective of social class background, complex home environments can disrupt young people's engagement with schooling because they may be called upon, as we have observed, to exercise independence at an early age, to care for younger siblings and disabled parents, to manage relationships with neighbours and service providers, and so on. While it is not the role of teachers to replace or substitute these primary relationships, even when complex, they can provide care and support that enhances young people's capacity to sustain their engagement in schooling. At Banksia College, for example, a teacher named Leigh, came up constantly in our interviews with young people. We heard numerous stories of how she went beyond the role of 'teacher' in the ways she cared for her students. In one discussion with students Callum and Leanne, they joked: 'Leigh needs to clone herself!' and Leanne added 'Yeah - we need more Leighs!' Evidence of her high level of care was threaded through all the data from Banksia College. For example, in a discussion about the food available at the site, the conversation indicated that packs of noodles were once provided for students but this is no longer the case. Darren commented: 'Don't have them lately. If it was really bad, Leigh would probably just give you some money to go to the canteen or something’. And Robbie,

I missed out on a lot of schoolwork because I was really sick, that was due last semester - not last semester, last term. And I have been allowed to catch up pretty much nearly all of it. In the last few days, I was supposed to get some other work done, but my mother is in hospital now. So Leigh is supporting me and making sure that I can get to places easily ... Pretty much anything that she can do, like, transport - I believe she's done it for other people. 
It appeared that Leigh's approach was to develop modes of caring that were appropriate for the needs of individual students as summed up here by Leanne:

Yes, she works - she has a different relationship - she has a relationship with everyone but it's different, which is really good. She sits there and knows everyone but she will have to change her, like, talking and that. She's like, 'Alright, I am talking to this student now, so I have got to talk to her in this way', you know what I mean. Yeah, she's really good.

In the case of marginalised students, care and support is likely to involve solidarity expressed through curriculum and pedagogy that values, respects, and builds upon the knowledge and cultural backgrounds of students, while also supporting their capacity to engage with the kinds of knowledge that contribute to success at school and beyond. This is a challenge faced by teachers in both alternative and mainstream settings. However, for the former, it requires findings ways to engage young people in learning that do not involve repeating or reinforcing students’ prior experiences of failure (Hayes, 2012).

We contend that a concern with 'affective equality' is critical to the success of alternative schooling. This is achieved relationally and academically. We suggest that, as with the dimensions of justice outlined in Fraser's work, both types of affective equality are necessary, and neither is sufficient on its own for considering what makes up a socially just school. Kim and Taylor (2008), for example, examine one alternative school in the mid-west of the United States, attended by many young people who have not been served well by current educational practices, to explore the benefits or otherwise of this school for its students. Their view was that the school was, indeed, a caring place; however, they were also of the view that it did little to break 'the cycle of educational inequality’ (Kim \& Taylor, 2008, p. 208). In this school, many of the students indicated that they wanted to go to college; however, the school's focus on 'credit recovery',where students who have fallen behind on their grades or school work attempt to catch 
up with their peers in the mainstream school, did not facilitate this goal. However, as Kim and Taylor (2008) go on to say: 'Their dreams required a more rigorous college-bound curriculum and career counselling’ (p. 213). Echoing de Jong and Griffiths (2006), Kim and Taylor (2008) claim that:

A school program is beneficial to students when it provides content, processes, rigor, and concepts that they need to develop and realize their future career goals. A school program that is beneficial to students engages them and leads them through varying processes to critical thinking and synthesis of the concepts and content. Conversely, a school program that is not beneficial to students is behavioristic, positivistic, and reductive. That is, the focus of the program is primarily on an either-or dichotomy: It addresses only lower order thinking and processing skills and does not move students toward their future career goals. (p. 208)

Others to critique the types of learning taking place in such settings include Thomson and Russell (2007) in the UK who suggest there was a tendency to assume that all young people in alternative learning environments need and want is vocational options, which limits scope of provision (p. viii). Similarly, Dovemark and Beach (2014) in Sweden demonstrated some of the ways in which deficit understandings of students in a program for non-academic, non-vocational students contributed to their already precarious existence. In such instances it is imperative that teachers and workers in alternative schools become advocates for young people, enacting Lynch's notion of 'solidarity' in caring for the long-term prospects of their students. We have also witnessed the absence of engaging, intellectually challenging and meaningful classroom practice in the alternative schools that formed part of our study, as illustrated here by Anthony, a student at Boronia Flexi School, who commented about his English studies:

The quality of work - for instance, if I was still going to [name of previous school] I'd be expected to do, in English say, a 3,000-word essay. You're not expected to do that in English here. 
Both Anthony and another student, Colin, agreed that classes at the flexi school were 'a lot easier’. When asked if they liked their current situation, Anthony replied:

Yeah, it’s good because it's a lot less workload, but bad because ... I honestly don't feel like I learn anything, like what I haven’t already learned. It just feels like I’m just repeating.

The development of an appropriate and challenging curriculum for their students was clearly of great concern to the teachers in our case study schools. This kind of curriculum work is made even more complex in these settings because the students come from a variety of background learning experiences. Teachers are required to assess each student's learning needs and preferences, and map these to appropriate curriculum pathways. Maddy, a teacher at Elkhorn Community College, for example, explained how she got to know her student as learners:

I have just recently started trying to do, "what kind of learner am I?" That starts with a worksheet thing where they grade - put a scale, you know. They answer questions and then we have conversations, "Why do you learn best in this way? What can we do in this setting to make it most beneficial for you, and the best way that I can support you in your learning?"

We acknowledge that many of the students who attend alternative schools have significant educational gaps that need to be addressed. Our concern is that rather than bridging the gaps and moving the learning forward, the 'gaps' will remain if learning is restricted to basic skills such as literacy and numeracy and 'job readiness'.

Branson from Elkhorn Community College spoke about a class that is offered at his college called Employment, Education and Training:

We have got a class that we can go to, if we want to do our job searches, résumés, certificates, get work experience. Yeah, I have got a couple so far. Heaps of stuff. It's pretty good here. TAFE is just down the road, so they take us down there in the bus, or they will come here; instead of finding your own way to TAFE. 
In our experience, this state of affairs, as in lower streamed classes in mainstream schools, and lower expectations across whole schools located in low socioeconomic and marginalised communities, is justified often on the grounds of deficit understandings of students' abilities and dispositions. The absence of student work premised on high expectations and engaging activities, and the justifications for this absence, would not be present in classrooms for 'gifted and talented' students or in schools proud of their academic reputations. Such attitudes may signify a lack of intellectual care and respect for the young people, their current abilities and their future potential. In recognising that there is a need to go beyond care, and indeed solidarity, as with Lynch, we have engaged with the work of Sayer and the notion of contributive justice. We argue here that this understanding of justice is crucial in ensuring that alternative schools consolidate their ethos of care as a basis for ensuring that their students have access to meaningful learning.

\section{Contributive justice and meaningful learning}

Whilst affective justice has a focus upon care of and respect for the individual in terms of the material, relational and intellectual supports and opportunities provided, contributive justice (Gomberg, 2007; Sayer 2009; 2011) is overtly concerned with what a person actually gets to do. Sayer (2011) states that: 'contributive justice concerns what people are allowed, expected or required to do or contribute' (p. 9). As such it contrasts with, but complements justices concerned with what a person gets (economic), who a person is (cultural), how a person is heard (political) and how a person is cared for (affective). He goes on to argue that:

What people are allowed to contribute, particularly in terms of work, is at least as important as what they get in terms of resources, because the type of work that they do has far-reaching effects on the kinds of people they become, on how they view themselves and are viewed by others, and hence on the quality of their lives. (Sayer, 2011, p. 9) 
This is an echo of his distinction between contributive justice and economic justice, when he argues that: 'what we do in life has at least as much influence on who we become and the quality of our lives, as does what we get' (Sayer, 2009, p. 2). For Sayer, there are two aspects to contributive justice. The first has a quantitative element to it and is concerned with doing a 'fair share' of the workload. Teachers, and indeed university academics, who set project work and group tasks are familiar with the complaints that others are not pulling their weight or are taking over - both relate to the notion of contributive justice. However, whilst important, we are more concerned here with the qualitative element of contributive justice. This relates to the type of work being done and the intrinsic and extrinsic rewards associated with this work. It also relates to the opportunities that people have to make a contribution to the conception and execution, and all stages in between, of a shared project. This form of injustice is also linked and works closely with those frames identified by Fraser. For example, there are times when boring, repetitive, low skilled tasks are necessary to complete a project. However, how those tasks are distributed and rewarded is a matter of social justice. The unfair distribution of work occurs in both the formal economy and in domestic life. In the formal economy contributive injustice, according to Sayer, occurs both within and between occupations and workplaces.

Sayer provides a set of arguments from Murphy (1994) and Gromberg (2007), to indicate why this state of affairs is unjust. These all relates to a person's quality of life. The kind of work that a person does has an impact upon who they become and on their emotional, physical and intellectual well-being. People experience enjoyment in doing complex tasks that enable them to employ and extend their capacities (see Griffiths, 2012, for a discussion of social justice and (joy’). For example, Lilly from Banksia College who, after fleeing there from an abusive family relationship in another major city, had been homeless in the ACT, before finding her way to the 
College, excitedly told us about how she wanted to build her own computer and noted: 'At the moment I am working towards getting an IT apprenticeship - I would never been able to finish Year 12 without [this program]'.

Dignity is also enhanced when people have control over their labour in that they are trusted, understand their contribution to the larger project, and have an opportunity to question their and others' roles throughout the process of conception and execution of a project. Understanding the various links in a project and reasons for embarking on a particular task also ensures that even mundane tasks when shared around are meaningful. There is great resonance here with schooling and classroom work. This was evident when Stuart, the teacher in charge of the alternative program at Banksia College, was describing the types of projects they undertook in their program. A key aspect of their work involved students working on a range of tasks, including some menial ones, to develop a product that had real world impacts. Stuart told us:

[For our next project] we are going to aim to make some swags ${ }^{3}$ with an industrial sewing machine, roll them with toothpaste, toothbrushes, towel, whatever we find, soap, and then we will give them to one of our local homeless shelters for the winter because it's pretty harsh in [the city] - well, you know, it is not pleasant anyway. So wherever possible we take a leadership or a community service thing in addition.... We don't have too many students who wallow and they have - pretty much all have had difficult circumstances.

In this case it was indicated that the students were proud of their achievements and developing a sense of contributing to their community.

Students who are deemed to be the most competent are often those most likely to be provided with opportunities to extend themselves and to receive diverse learning experiences (see for example, Charlton et al., 2007). Similar parallels can be found with a differentiated

\footnotetext{
${ }^{3}$ An Australian colloquial term for a bedroll containing all one’s personal belongings.
} 
schooling system where certain schools specialize in academic learning and others have a more technical focus. The growing presence of flexible learning options points to a schooling system that is increasingly diversifying in ways that have the potential to exacerbate this situation (Hayes, 2013; Slee, 2011). The defence of such arrangements include arguments to the case that it is more efficient to have specialized or differentiated schools and classrooms that cater to differences in abilities, interests and behaviours. This, it is sometimes argued, helps to ensure that the schooling system is efficient, that it is stabilized in that disruptions and poor behaviours are minimized (at least to the extent that 'good students' do not have their work interfered with) and that this situation caters to different abilities, potential and dispositions. However, Bardsley (2007) has argued that:

Where social stability and economic efficiency are valued above all else, the aim of education becomes the provision of basic skills to train citizens amongst the socioeconomically deprived classes to perform the menial tasks essential to keep society functioning, without disrupting established power structures (Laberee, 1997; Lynch \& Lodge, 2002). Justice within education systems should be committed to the premise that all children must be adequately prepared for effective societal roles of their own choosing. (p.496)

Bardsley’s (2007) work also suggests that a socially just education has to provide young people with the skills and knowledge to engage with 'emerging societal contexts'. This will entail school work engaging with technology, developing critical citizenship skills and understandings of contemporary society.

It is our contention that contributive justice is present in a classroom when students are presented with learning opportunities that enable them to develop a sense of pride in the outcomes of that learning - in much the same way that a craftsperson feels pride in the 
construction of a product (Sennet, 2009). This recount from Stuart, a deputy and head of the alternative program at Banksia College, exemplifies this contention:

We have Miriam who all of last year spent six months making polymers with one of our chemistry teachers and she explained it to me ... And she's a pretty eclectic little thinker. ... I missed the exhibition where her family came to the exhibition... And the family sees something that the kid is proud of and there is a moment where they do a little bit of readjustment. Yeah, they settle back - there is that moment when the kid goes, 'Oh, you do actually see something good about me. I am making progress', and that's transformative for both sides. We have got parents that were reviewed as part of that review process. They are some of our biggest fans. As I said, they have enrolled second kids in it. I think that what they like about it is the concept that the kid has to do something fairly rigorous.

At Boronia Flexi School, the music teacher provided a similar example:

The staff and the students see people walking out of this room with such big chests, you know. The pride is just visibly obvious to see when they have just had some success. That I think is, I am not saying it is all about music, but some sort of high level professional product that is in the digital domain I think every school would benefit from.

What the data from our research indicate is that such learning occurs when it is has a purpose (whether personal or instrumental) and that that purpose is evident to the student. Julian (a teacher at Boronia Flexi School) linked this to 'a sense of empowerment for the young people to be who they feel as though they want to be'. It also has some connection to the world beyond the classroom and stretches and challenges all young people, not just those deemed to be of 'high ability’.

\section{Conclusion}

Our concern with what a socially just schooling system might look like and, in particular, how 
schools can meet the needs of the most marginalised students, led us to explore 'what works' in those schools catering to students who have been excluded from mainstream schools or have themselves rejected what the mainstream has to offer. In many instance we have been impressed by these schools' efforts to address economic, cultural and political injustices. In this paper, we have thus contended that a socially just education for students attends to Fraser's $(1997 ; 2009)$ dimensions of social justice in respect of economic, cultural and political inequities. However, drawing upon the work of Lynch (2012) and Sayer (2009, 2011), we have also argued that these dimensions are enhanced by the inclusion of affective and contributive forms of justice, which pay attention to inequities in relational care and individual potential for meaningful participation.

The teacher participants in our study expressed a strong commitment to the social and emotional well-being of their students. Affective justice (in the forms of significant support structures and respectful, caring relationships) was of primary concern to them. Many of the students we interviewed indicated that its absence in their former school(s) had been a key factor in their departure from the mainstream sector. This concern with affective justice was thus critical to the success of such schools. However, we suggest that if it exists in isolation from other necessary elements, care is insufficient for ensuring the provision of socially just schooling. The quality of curriculum and pedagogy, which varied in some instances across the sites, is also of critical concern, and hence why we also argue that contributive justice needs to be incorporated into concerns about affective justice.

In this paper we have indicated examples of where we have come across flexible learning arrangements that facilitated students' engagement in meaningful learning, demonstrating a commitment to contributive justice; however, there were sometimes reservations expressed. In some instances teachers indicated that in their alternative setting some students were not able to 
tackle challenging work and that this was why they were in the alternative school in the first place. Because of the patchy nature of the educational backgrounds of young people in alternative education, there was often a focus on literacy, numeracy and vocational options. Clearly these skills are necessary for economic participation in society; however, if such competencies and training are considered sufficient education for these, usually marginalized and disadvantaged, young people it could be argued that this may also condemn them to a lifetime of political and social marginalisation despite their ability to obtain employment. We thus argue that the quality of curricular choices and pedagogical approaches made available to young people in alternative education sites is fundamental to the achievement of contributive justice, and hence social justice. We are also of the view that concerns with affective justice and contributive justice should have occurred long before students such as those interviewed for this project found themselves in alternative education provision.

\section{References}

Abrams, F. (2010). Learning to fail: How society lets young people down. London, Routledge.

Bardsley, K. (2007). Education for all in a global era? The social justice of Australian secondary school education in a risk society. Journal of Education Policy, 22(5), 493-508.

Baroutsis, A., McGregor, G., \& Mills, M. (in press). Pedagogic voice: Student voice in teaching and engagement pedagogies. Pedagogy, Culture and Society. Accepted 22 January, 2015.

Beane, J. A. \& Apple, M.W. (1999). The case for democratic schools, in: M.W. Apple \& J.A. Beane (Eds.), Democratic schools: Lessons from the chalk face. Buckingham: Open University Press.

Beck, K. \& Cassidy, W. (2009). Embedding the ethics of care in school policies and practices, in: K. te Riele (Ed.). Making schools different: Alternative approaches to educating young people (pp. 55-64). London: SAGE

Bingham, C. \& Sidorkin, A. (Eds.) (2004). No education without relation. New York: Peter Lang Publishing 
Black, R. (2011). Student participation and disadvantage: Limitations in policy and practice, Journal of Youth Studies, 14(4), 463-474.

Blackmore, J. (1999). Troubling women: Feminism, leadership and educational change. Buckingham: Open University Press.

Blackmore, J. (2006). Social justice and the study and practice of leadership in education: A feminist history. Journal of Educational Administration and History, 38 (2), 185-200.

Boler, M. (1999). Feeling power: Emotions and education. New York: Routledge.

Charlton, E., Mills, M., Martino, W., \& Beckett, L. (2007). Sacrificial girls: A case study of the impact of streaming and setting on gender reform. British Educational Research Journal, 33(4), 459-478.

Cribb, A. \& Gewirtz, S. (2003). Towards a sociology of just practices, in: C. Vincent (Ed.) Social justice education and identity (pp. 15-29). London: Routledge.

Darling-Hammond, L. (2010). The flat world and education: How America's commitment to equity will determine our future. New York: Teachers College Press.

de Jong, T. \& Griffiths, C. (2006). The role of alternative education programs in meeting the needs of adolescent students with challenging behaviour: Characteristics of best practice. Australian Journal of Guidance \& Counselling, 16(1), 29-40.

Dewey, J. (1916). Democracy and education: An introduction to the philosophy of education. New York: Macmillan.

Dovemark, M. \& Beach, D. (2014). Academic work on a back-burner: Habituating students in the upper-secondary school towards marginality and a life in the precariat. International Journal of Inclusive Education, DOI: 10.1080/13603116.2014.961676.

Evans, J., Meyer, D., Pinney, A., \& Robinson, B. (2009). Second chances: Re-engaging young people in education and training. Essex: Barnardo's.

Falzon, M.-A. (2009). Introduction, in: M.-A. Falzon (Ed.), Multi-sited ethnography: Theory, praxis and locality in contemporary research (pp. 1-23). Surrey, England: Ashgate.

Fielding, M., \& Moss, P. (2011). Radical education and the common school: A democratic alternative. London: Routledge.

Fraser, N. (1997). Justice interruptus: Critical reflections on the 'postsocialist' condition. New York: Routledge. 
Fraser, N. (2009). Scales of justice: Reimagining political space in a globalizing world. New York: Columbia University Press.

Gale, T. \& Densmore, K. (2000) Engaging teachers: towards a radical democratic agenda for schooling. Buckingham: Open University Press.

Gomberg, P. (2007). How to make opportunity equal: Race and contributive justice. Malden MA: Blackwell Publishing.

Griffiths, M. (2012). Why joy in education is an issue for socially just policies. Journal of Education Policy, 27(5), 655-670.

Hardy, I. (2013). A logic of appropriation: Enacting national testing (NAPLAN) in Australia. Journal of Education Policy, 29(1), 1-18.

Hayes, D. (2012). Re-engaging marginalised young people in learning: the contribution of informal learning and community-based collaborations. Journal of Education Policy, 27(5), 641-653.

Hayes, D. (2013). Customization in schooling markets: the relationship between curriculum and pedagogy in a 'pop-up' learning project, and the epistemic opportunities afforded by students’ interests and backgrounds. International Journal of School Disaffection, 10(2): 3-22.

Hayes, D., Mills, M., Christie, P. and Lingard, B. (2006). Teachers and schooling making a difference: Productive pedagogies, assessment and performance. Crows Nest, Australia: Allen \& Unwin.

Hochschild, A. (1983). The managed heart. Berkeley, CA: University of California Press.

Kane, J. (2011). Social class, gender and exclusion from schools. London: Routledge.

Keddie, A. (2012a). Schooling and social justice through the lenses of Nancy Fraser. Critical Studies in Education, 53(3), 263-279.

Keddie. A. (2012b). Educating for diversity and social justice. New York: Routledge.

Kim, J.-H. (2011). Narrative inquiry into (re)imagining alternative schools: A case study of Kevin Gonzales. International Journal of Qualitative Studies in Education, 24(1), 77-96.

Kim, J-H \& Taylor, K. A. (2008). Rethinking alternative education to break the cycle of educational inequality and inequity. The Journal of Educational Research, 101(4), 207219. 
Kraftl, P. (2013). Geographies of alternative education: Diverse learning spaces for children and young people. Bristol: Policy Press.

Lingard, B. \& Sellar, S. (2013). 'Catalyst data’: Perverse systemic effects of audit and accountability in Australian schooling. Journal of Education Policy, 28(5), 634-656.

Lingard, B., Martino, W. \& Rezai-Rashti, G. (2013). Testing regimes, accountabilities and education policy: Commensurate global and national developments. Journal of Education Policy, 28(5), 539-556.

Lipman, P. (2008). Mixed-income schools and housing: advancing the neoliberal urban agenda. Journal of Education Policy, 23(2), 119-134.

Lynch, K. (2012). Affective equality as a key issue of justice: A comment on Fraser’s 3dimensiponal framework. Social Justice Series, 12(3), 45-64.

Marcus, G.E. (1995). Ethnography in/of the world system: The emergence of multi-sited ethnography. Annual Review of Anthropology, 24, 95-117.

McGregor, G., Mills, M., te Riele, K., \& Hayes, D. (2015). Excluded from school: Getting a second chance at a 'meaningful' education. International Journal of Inclusive Education, 19(6), 608-625.

Mills, C. \& Gale, T. (2010). Schooling in disadvantaged communities: Playing the game from the back of the field. Dordrecht, Netherlands: Springer.

Mills, M. \& McGregor, G. (2014). Re-engaging young people in education: Learning from alternative schools. London: Routledge.

Mills, M. \& McGregor, G. (2010). Re-engaging students in education: Success factors in alternative schools. Brisbane, Australia: Youth Affairs Network Queensland.

Mills, M., McGregor, G., Hayes, D., \& te Riele, K. (2015). 'Schools are for us': The importance of distribution, recognition and representation to creating socially just schools. In K. Trimmer, A. Black \& S. Riddle (Eds.), Researching Mainstreams, Margins and the Spaces In-Between (pp. 150-167), London: Routledge.

Mills, M., McGregor, G., Martin, B., Tomaszewski, W. \& Waters, R. (2014). Engaging young people in education. Brisbane, Australia: Department of Education, Training and Education. 
Mills, M. McGregor, G. \& Muspratt, S. (2013). Flexible learning options/centres in the Australian Capital Territory (ACT). Canberra, Australia: ACT Education and Training Directorate.

Mills, M., Renshaw, P., \& Zipin, L. (2013). Alternative education provision: A dumping ground for 'wasted lives' or a challenge to the mainstream? Social Alternatives, 32(2), 13-18.

Mosen-Lowe, L. A. J., Vidovich, L. \& Chapman, A. (2009). Students ‘at-risk’ policy:

Competing social and economic discourses. Journal of Education Policy, 24(4), 461-476.

Murphy, J.B. (1994). The moral economy of labor. New Haven: Yale.

Noddings, N. (1988). An ethic of caring and its implications for instructional arrangements. American Journal of Education, 96(2), 215-30.

OECD. (2012). Equity and quality in education: Supporting disadvantaged students and schools. Paris: OECD Publishing. Available http://dx.doi.org/10.1787/9789264130852-en (Accessed 13 May 2015).

Olsen, K. (Ed.) (2008). Adding insult to injury: Nancy Fraser debates her critics. London: Verso.

Pierides, D. (2010). Multi-sited ethnography and the field of educational research. Critical Studies in Education, 51(2), 179-195.

Power, S. \& Frandji, D. (2010). Education markets, the new politics of recognition and the increasing fatalism towards inequality. Journal of Education Policy, 25(3), 385-396.

Sayer, A. (2009). Contributive justice and meaningful work. Res Publica, 15, 1-16.

Sayer, A. (2011). Habitus, work and contributive justice. Sociology, 45(1), 7-21.

Sennett, R. (2009). The craftsman. London: Penguin Books.

Slee, R. (2011). The irregular school: Exclusion, schooling and inclusive education. London: Routledge.

Smyth, J. (2006). Educational leadership that fosters ‘student voice'. International Journal of Leadership in Education: Theory and Practice, 9(4), 279-284.

Smyth, J., Angus, L., Down, B., \& McInerney, P. (2008). Critically engaged learning: Connecting to young lives. New York: Peter Lang Publishers

Smyth, J., McInerney, P., \& Fish, T. (2013). Re-engagement to where? Low SES students in alternative-education programs on the path to low-status destinations? Research in PostCompulsory Education, 18(1-2), 194-207. 
Te Riele, K. (2006). Schooling practices for marginalized students - practice-with-hope. International Journal of Inclusive Education, 10(1), 59-74.

te Riele, K. (2007). Educational alternatives for marginalised youth. Australian Educational Researcher, 34(3), 53-68.

te Riele, K. (2011). Raising educational attainment: How young people's experiences speak back to the Compact with young Australians. Critical Studies in Education, 52(1), 93-107.

Te Riele, K. (2012). Negotiating risk and hope: A case study of alternative education for marginalized youth in Australia. In W. Pink (Ed). Schools and marginalized youth: An international perspective (pp. 31-79). Cresskill (NJ): Hampton Press

Te Riele, K. (2014). Putting the jigsaw together: Flexible learning programs in Australia. Final report. Melbourne: The Victoria Institute for Education, Diversity and Lifelong Learning. Available: http://dusseldorp.org.au/priorities/alternative-learning/jigsaw/

Te Riele, K., Davies, M. \& Baker, A. (2015). Passport to a positive future. Evaluation of the Melbourne Academy. Melbourne: The Victoria Institute for Education, Diversity and Lifelong Learning. Available: http://www.vu.edu.au/sites/default/files/victoriainstitute/pdfs/Passport-to-a-Positive-Future-\%28web\%29.pdf

Teese, R. \& Polesel, J. (2003). Undemocratic schooling: Equity and quality in mass secondary schooling in Australia. Melbourne: Melbourne University Press.

Thomson, P., \& L. Russell, L. (2007). Mapping the alternatives to permanent exclusion. York: Joseph Rowntree Foundation. 